\title{
PREHISTORICAL Pediculus humanus capitis INFESTATION: QUANTITATIVE DATA AND LOW VACUUM SCANNING MICROSCOPY
}

Juliana M.F. DUTRA(1), Arthur Daniel ALVES(1), Thaila PESSANHA(1), Rachel RACHID(2), Wanderley de SOUZA(2), Pedro Marcos LINARDI(3), Luiz Fernando FERREIRA(1), Sheila Mendonça de SOUZA(1) \& Adauto ARAUJO(1).

\begin{abstract}
SUMMARY
A pre-Columbian Peruvian scalp was examined decades ago by a researcher from the Oswaldo Cruz Foundation. Professor Olympio da Fonseca Filho described nits and adult lice attached to hair shafts and commented about the origin of head lice infestations on mankind. This same scalp was sent to our laboratory and is the subject of the present paper. Analysis showed a massive infestation with nine eggs $/ \mathrm{cm}^{2}$ and an impressive number of very well preserved adult lice. The infestation age was roughly estimated as nine months before death based on the distance of nits from the hair root and the medium rate of hair growth. A small traditional textile was associated with the scalp, possibly part of the funerary belongings. Other morphological aspects visualized by low-vacuum scanning electron microscopy are also presented here for adults and nits.
\end{abstract}

KEYWORDS: Pediculus humanus; Head lice; Paleoparasitology; Human hair; Parasitism; Evolution.

\section{INTRODUCTION}

The family Pediculidae includes two types of lice that uniquely infest humans and are generally site-specific: Pediculus humanus capitis (the head louse) and Pediculus humanus humanus (the body louse), also considered by some authors as distinct species, in spite of molecular studies evidenced that they are conspecific ${ }^{15,16}$. Fertilized eggs of sucking lice are referred to as nits and are firmly cemented to the hair shaft. Subsequently, eggs develop through three nymph instars before achieving adulthood ${ }^{5,9}$.

Lice infestation is dated from 25 million years ago (MYA) in primates $^{22}$. At 6 MYA mark humans and monkeys are supposed to take different evolutionary ways ${ }^{21,22}$. Lice infestation is mentioned in the Bible as the third plague punishing the Egyptians when the Pharaoh denied the request of Moses to set the Israelites free - "when all the dust throughout the land of Egypt became lice".

Evidence of louse infestation in archeological samples came with RUFFER ${ }^{26}$ studies in Egyptian mummies from the Royal dynasty. The dynamics of infestation and transmission of head and body louse in the past is very well documented in many publications on the issue $e^{1,3,8,11,14,21,24}$. Hair samples, hair attached to the skull, in the form of scalp or fragments found in urns, carry lice and nits that have not yet been dated in the timeline of man's presence in the Americas. The world's oldest known direct head-louse association - a nit on a human hair - was found at a 10,000 year old archaeological site in northeastern Brazil ${ }^{1}$.
Lice infestation in ancient populations is associated to different groups, economic conditions and periods; hygiene and cultural habits determine the prevalence and frequency of infestation in human groups. A double infestation by Pediculus capitis and Pthirus pubis (pubic louse) was described by FORNACIARI et al. ${ }^{11}$, in the mummy of the King of Naples, Ferdinand II of Aragon (1467-1496). Another relevant episode of body lice infestation including parts of the abdomen or the dorsum of five lice evolved in Napoleon's soldiers in Vilnius, when Napoleon Bonaparte besieged the city in 1812, during the Russian Campaign ${ }^{20}$. Evidence of ancient lice infestation in America was improved by the studies of mummies from the Chiribayan culture ${ }^{23}$, Chinchorro culture ${ }^{25}$ and others from northern Chile ${ }^{3}$.

Studying nits in mummified bodies is quite simple, since they keep attached to the hairs even after death. If no grooming or other strategy help to get rid of them, the dead nits can persist for a long time firmly attached, being preserved in the mummified bodies and loose hairs. LINARDI et al. ${ }^{17}$ proposed that nit persistence on hair shafts could help to estimate the time lapse of the infestation, using the distance between the nit and the scalp as a reference. On the other hand, the finding of adult lice is more surprising, because they are expected to abandon the body of the deceased soon after death, because of the cooling of the corpse.

Here, we reviewed a case of louse infestation in a scalp of Peruvian origin. A previous description of this scalp was presented by FONSECA FILHO ${ }^{10}$ which mentioned only the finding of nits and lice in the sample. From that, the elevated number of nits and lice called our attention and

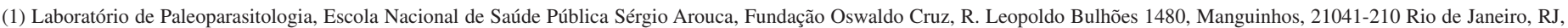
Brazil. Tel.: +55 (21) 2598-2566.

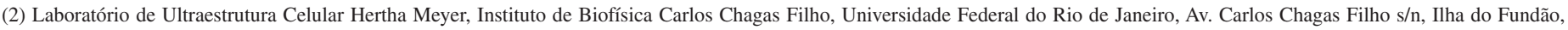
21941-902 Rio de Janeiro, RJ, Brazil.

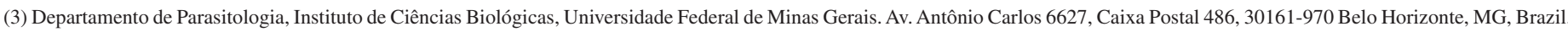
Correspondence to: Juliana M.F. DUTRA, E-mail: jsantiago@ensp.fiocruz.br 


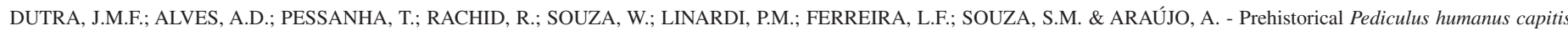
infestation: quantitative data and low vacuum scanning microscopy. Rev. Inst.Med. Trop. Sao Paulo, 56(2): 115-9, 2014.

a more detailed investigation was carried out using new methods for estimating the infestation and low vacuum scanning electron microscopy for parasite documentation.

\section{MATERIAL AND METHODS}

Human scalp and hair sample: In 1981, Dr. Dorath Pinto Uchoa, archaeologist of the Museu de Arqueologia e Etnologia da Universidade de São Paulo, Brazil, sent to the Laboratory of Paleoparasitology of ENSP/FIOCRUZ the present scalp for paleoparasitological examination. The scalp was said to belong to the private collection of Paulo Duarte, a famous Brazilian anthropologist, and had been previously examined by professor Olympio da Fonseca Filho, probably in 1960's.

The material consists of fragments of different sizes of a human scalp and some loose hair shafts containing lice and nits. The fragments suggest that the piece was rotten and the skin/hairs were cut in some areas, possibly to provide minor samples for analysis. The hair was partially lost and was cut into different segments, a signal of destructive bioactivity. In the mummified scalp the skin is thin and elastic but most of the hairs still have their roots firmly inserted in site. The dark brown hairs are flexible and there is no signal of discoloration. Putting the different fragments together and respecting the orientation of the hairs it is possible to confirm that it was originally a bigger scalp, possibly from the top and back parts of the head.

Quantitative analysis for nit size: The methodology follows REINHARD \& BUIKSTRA ${ }^{23}$.

After the first examination, four different fragments of the scalp, identified as A, B, C and D respectively, were selected for quantitative studies. The biggest fragment measured $6.7 \times 4.4 \mathrm{~cm}$ (length $\mathrm{x}$ width) and three smaller ones sized between 2 and $5 \mathrm{~cm}$ were used for counting nits and adults. For counting nits a 2 × $2 \mathrm{~cm}$ square window was cut into a cardboard paper and placed above different regions of each fragment. The nits inside each of those delimited areas were counted. A total of three windows were counted.

For bright field microscopy analysis, fifty nits were separated randomly under a stereomicroscope. After 72 hours of rehydration in trisodium phosphate $0.5 \%$ aqueous solution ${ }^{6}$ the nits were mounted on glass slides for observation. All were measured and photographed under a Primo Star microscopy associated with Zen ${ }^{\circledR}$ software (Carl Zeiss), in a final magnification of 100x.

Infestation profile: In order to analyze the infestation profile, ten hair shafts with nits were separated randomly from each fragment and measured. Hair shaft length and the distance between nit position and the scalp were measured using a millimeter scale, following LINARDI et al. ${ }^{17}$. The maximum number of nits per shaft was also calculated.

Scanning electron microscopy: Nits and adults were observed under low-vacuum scanning electron microscopy (SEM). For SEM preparation, four nits were rehydrated as previously described at item 2 , then washed in distillated water and dried at room temperature. Hair shafts were mounted on stubs with double side carbon tape (TED PELLA Inc.) and examined in a low-vacuum SEM at QUANTA 250 (FEI Company). Adults were not rehydrated before SEM observation.
Fifty nits were randomly selected and prepared for light microscopy after rehydration and measured in length and width. The morphological aspect of nits was also evaluated (Fig. 1). For inside nit exposition, the hair shaft containing nits was mounted on a stub with a double side carbon tape. In the sequence, adhesive tape was stuck on the top to remove the superficial layer of the sample. Both halves were observed under lowvacuum SEM as described above.

\section{RESULTS}

The results presented here were conclusive for heavy infestation determined by the high density of nits in the scalp, as summarized in Table I. All the fragments of the scalp showed a high-density value of nits, ranging from 3.5 nits $/ \mathrm{cm}^{2}$ to 9.5 nits $/ \mathrm{cm}^{2}$.

The morphological characteristics of the nits as well as adults, and the maximum width (average: $469.38 \pm 100 \mu \mathrm{m}$ ) and length (average: $1,126.92 \pm 221 \mu \mathrm{m}$ ) of the nit size showed no differences when compared with modern nits. The good state of preservation of nits/adults allowed a morphologically detailed description by light and scanning electron microscopy, helping to confirm its morphological characteristics and to compare with other descriptions in the literature (Fig. 1 and 2). Nymphs inside the eggs could be identified after the eggshell was removed with adhesive tape (Fig. 2B-2D).

A
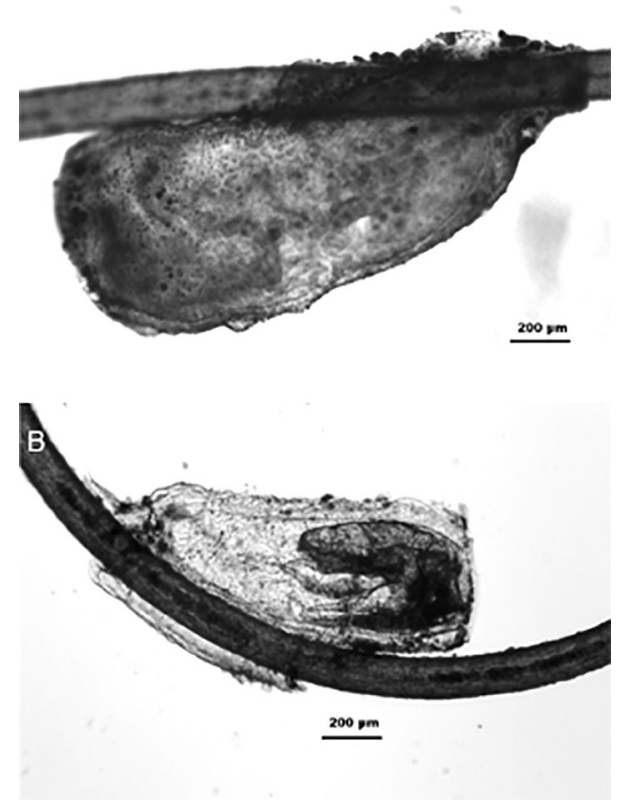

Fig. 1 - Eggs/nits under bright field microscopy. After the rehydration process, it is possible to visualize the embryonic stage inside the eggshell. 50 nits were measured: the size ranged between 1,126.92 $\mu \mathrm{m}$ (length) and $469.38 \mu \mathrm{m}$ (width). Scale bar $=200 \mu \mathrm{m}$.

The nit's position was useful to determine the time of infestation, and the distance from the hair root measured between $0.2 \mathrm{~cm}$ and 9.5 $\mathrm{cm}$ (Table I). The longest hair shaft measured in the scalp (fragment A) also showed the major distance from nits to skin. 


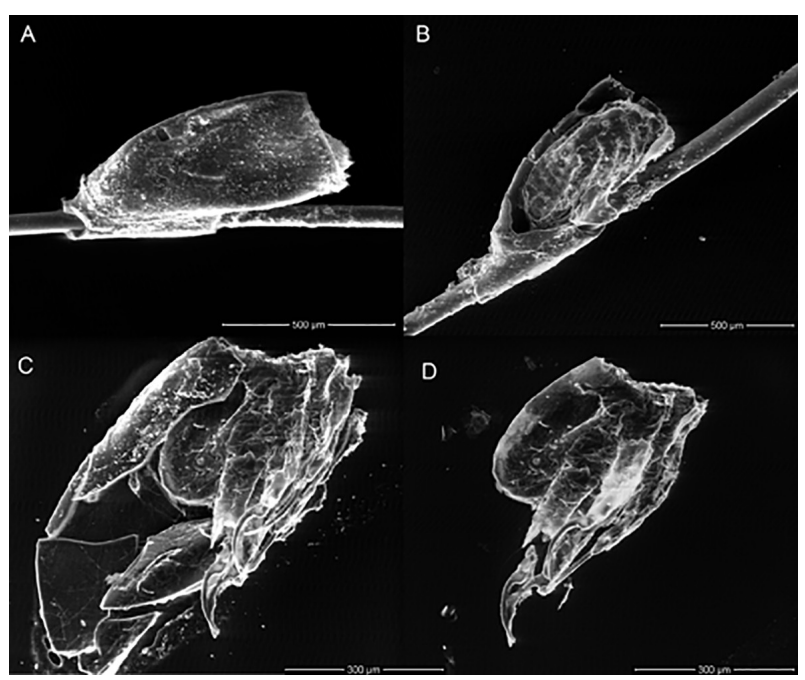

Fig. 2 - Low-vacuum scanning microscopy of eggs/nits attached to a hairshaft. The eggshell was removed with adhesive tape and showed the presence of a larvae hatching. Scale bar $=500 \mu \mathrm{m}$.

Table 1

Nits density and position on hair shaft

\begin{tabular}{lcccc}
\hline & \multicolumn{4}{c}{ Fragments } \\
\cline { 2 - 5 } & $\mathrm{A}$ & $\mathrm{B}$ & $\mathrm{C}$ & $\mathrm{D}$ \\
\hline Hair shaft length & 18 & 26 & 20 & 14 \\
$\quad$ Longest* & 5 & 5 & 4 & 5 \\
$\quad$ Shorter & 9.5 & 6 & 3.5 & 3.6 \\
$\quad$ Max. nits per area** & & & & \\
Distance of nits from scalp & 2.3 & 0.5 & 0.6 & 0.2 \\
$\quad$ Min. & $9.5 \dagger$ & 4.0 & 3.3 & 2.6 \\
$\quad$ Max. & 4 & 1 & 1 & 1 \\
$\quad$ Max. nits per hair shaft &
\end{tabular}

*centimeter scale; $* * 2 \times 2 \mathrm{~cm}$ square; $\dagger$ nit on the longest hair shaft found $(18 \mathrm{~cm})$.

Empty nits positioned $9.5 \mathrm{~cm}$ away from scalp points for a period of nine months before death as a possible infestation date. Other viable nits (Fig. 2B-2D) situated at $0.2 \mathrm{~cm}$ from the base of the scalp could signalize a minimum infestation age of 5-7 days before death, in accordance with the emergence of the first nymph instar ${ }^{5,13}$.

Low-vacuum SEM was used for morphological analysis in adults and nits. Adults showed a very well preserved state, with a flattened and desiccated body from the aging process (Fig. 3). It was possible to visualize lateral spiracles (Fig. 3A and $\mathrm{C}$ - arrows) and the genital aperture from females (Fig. 3D - asterisk). One female in particular that had lost a pair of antenna and the first pair of clawed legs, although the eyes were preserved (Fig. 3B).

\section{DISCUSSION}

Recent observations done by REINHARD AND BUIKSTRA ${ }^{23}$ also

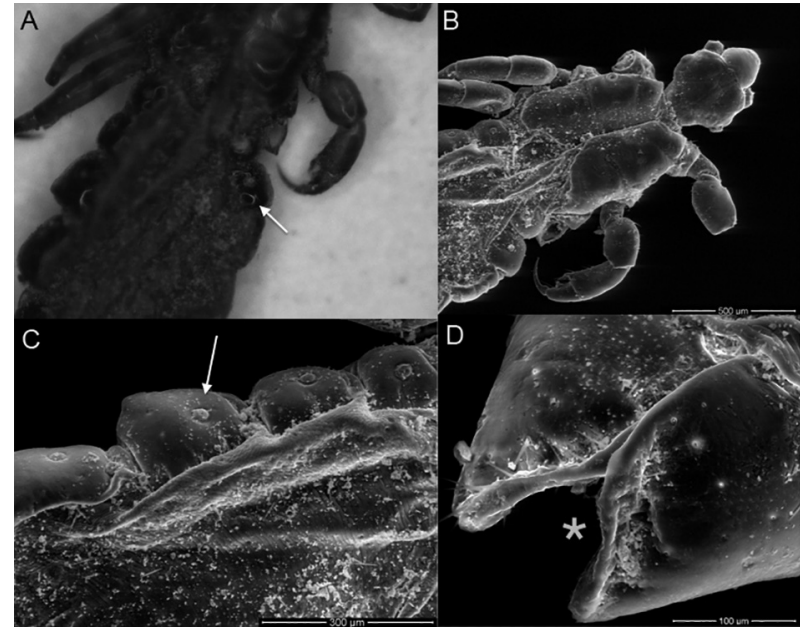

Fig. 3 - Adults seen under a stereomicroscope and by Low-vacuum scanning microscopy. It can be noted that the lateral spiracles were well preserved (Fig. 3A and C - arrows) and the genital aperture from females (Fig. 3D - asterisk).

showed an expressive infestation in Chiribaya people, an Andean group living around 900 and $1350 \mathrm{AD}$ in southern Peru. In that study the mean maximum louse density was 8.9 nits $/ \mathrm{cm}^{2}$ in cotton samples, but the value for all other sites studied was $2.28 \mathrm{nits} / \mathrm{cm}^{2}$. As stated by those authors, a mean maximum density ranging from five nits $/ \mathrm{cm}^{2}$ to $22 \mathrm{nits} / \mathrm{cm}^{2}$ represent heavy infestation, making the value found in the present case, of nine nits $/ \mathrm{cm}^{2}$, very representative. The finding of a heavy infestation seems not to be the rule even in people of the past of the Andean area, and special conditions must be considered here that may justify the present results. The unknown origin of the scalps prevents further detailed interpretation but one possible explanation is the individual condition, as also inferred by the papers cited above where we can find differences in individual infestation values, especially because one ill or handicapped people could be more susceptible to infestation. As in any culture in the past, age groups, sex and social conditions could all affect the possibility of regular hygiene practices/grooming and their benefits could be available to some individuals and not to others in the same group. The second possibility is that the scalp examined may come from one group more affected than others by the infestation ${ }^{23}$, and this could be associated with some special conditions such as periods of violence, crowding conditions, scarcity periods, imprisonment, and others moments of social disruption that would certainly affect the possibility of keeping traditional practices. In America, the contact period after the XVI century, as well as the troubled periods under the pressure of expanding dominant groups like Wari, Tiwaknaku or Inka could represent such situations ${ }^{19}$.

Adults and nits, as demonstrated by low-vacuum SEM pictures here, were an interesting finding. As stated before, although nits are usually found attached to hairs and scalps, the finding of adults, in considerable numbers, is not expected in such mummified samples, because the free adults try to abandon the corpse after death, maximizing their chances of survival and reproduction.

Following LINARDI et al. ${ }^{18}$, nits, nymphs and adults can be found alive 24 hours after removal from the host. Nits can still be attached to hair shafts even after death. A cement substance produced in the accessory glands of the louse is laid by females together with eggs; it prevents the 


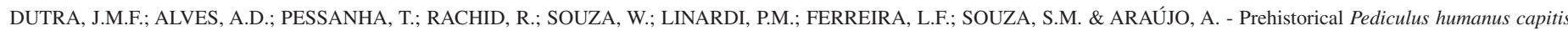
infestation: quantitative data and low vacuum scanning microscopy. Rev. Inst.Med. Trop. Sao Paulo, 56(2): 115-9, 2014.

egg from becoming unstuck from the hair shaft, even after the egg has hatched, and they migrate far from the scalp following hair growth ${ }^{17}$.

The dynamics of hair growth differ between ethnic groups, and vary with age, gender, body site and environmental changes. Physiological or pathological states such as pregnancy, malnutrition or disease can also modulate hair growth ${ }^{7}$. Assuming one $\mathrm{cm} / \mathrm{month}$ as a reasonable medium rate of growth for humans we can estimate the infestation time in this case. Otherwise, infestation time cannot be precisely estimated because many factors can change the equation, including the fact that human hair growth is variable in the same head ${ }^{12}$. Taking the heavy density of nits found and the multiple presences in a single hair shaft, this possible period of infestation does not seem so unlikely, even though it is impossible to determine other parameters that could impair hair growth in this individual. ARRIAZA et al. ${ }^{3}$, describing a Maita Chiribaya mummy lice infestation, also found a heavy infestation, confirming numerous specimens in different stages of development. The results were associated with the life style of the group. For REINHARD \& BUIKSTRA ${ }^{23}$ who first found a similar heavy infestation in the population of Chiribaya, the prevalence in men, instead of women and children, could point to differences in social attributes. They also described the combs used by those people. The practice of combing the hair is very well known for different native groups, and the special hairdressings using tresses and other special fashions among Andean groups inspired even modern stylists. The combing practices among women probably also helped to remove adults and minimize the symptoms of intense itching caused by P. $h$. capitis. Although ARRIAZA et al. ${ }^{2}$ and ARRIAZA \& STANDEN ${ }^{4}$ maintain that lice infestations should be endemic in the Andes region, because of the archaeological findings of fine combs possibly used for nits or adults removal, we must keep in mind that the existence of very sophisticated combing and dressing patterns in the Andean region goes beyond the possible functional lice-related practices. On the other hand, the endemicity of $P . h$. capitis is confirmed by the study of different samples as described in the literature. It was not possible to compare the total counting of 17 adult lice in this scalp with the finding of other authors because the present sample was fragmented, but it is possible to maintain that the individual had an active infestation when he/she died. The practice of wrapping corpses in order to prepare the funerary bundle may explain the persistence of the adults in the scalp after death, preventing them from abandoning the head. This makes us consider that differences in funerary practices certainly have an impact on the possibility of recovering or not, adult lice, and consequently, vary interpretations of final results in archaeological samples.

\section{CONCLUSION}

Lice infestation, one of the most antique host-parasite interactions was present in Andean groups, and the finding of well preserved adult forms, eggs and nits helps in their study over time and space. In the scalp we examined, the use of SEM techniques helped to confirm the good preservation of the parasites and to detail the description of the different stages (adult to nits) of the parasite present in the hairs or free in the scalp. The application of quantitative methods to estimate the number of nits per area of scalp, and the distance between the nits and the scalp, helped to compare the severity and antiquity of the infestation with other similar studies in South America. The infestation in the present case was considered intense, lasting for about nine months before death, being no doubt, active in the moment the individual died.
Finally, results proved to be a good opportunity to call attention to the beginnings of paleoparasitology in our country, as professor Olympio da Fonseca Filho was a pioneer on this matter describing parasites in archaeological material. As far as we know, he had the opportunity of examining this scalp years before he published his book in the early 1970 's ${ }^{10}$. The essence of paleoparasitology, while discussing the origins and evolution of host-parasite relationships, is present in his book.

\section{RESUMO}

\section{Infestação pré-histórica por Pediculus humanus capitis: análise quantitativa e por microscopia de varredura de baixo vácuo}

Há décadas um escalpo peruano, datado do período pré-colombiano, foi examinado por um pesquisador da Fundação Oswaldo Cruz. O Professor Olympio da Fonseca Filho descreveu lêndeas e adultos fixos a fios de cabelos e fez comentários sobre a origem da infecção por piolhos na espécie humana. Este mesmo escalpo foi enviado ao nosso laboratório e é objeto deste artigo. Sua análise mostrou maciça infestação, com nove lêndeas $/ \mathrm{cm}^{2}$ em impressionante número de adultos muito bem preservados. O tempo de infestação foi estimado em cerca de nove meses antes da morte, baseado na maior distância entre lêndeas e o couro cabeludo, levando em consideração taxa média de crescimento capilar de $1 \mathrm{~cm}$ por mês. Um pequeno pedaço de tecido tradicional peruano foi encontrado associado ao escalpo, provavelmente pertencente ao conjunto de peças usado no ritual funerário. Aqui, apresentamos alguns aspectos morfológicos de adultos e lêndeas vizualizados por microscopia eletrônica de varredura de baixo vácuo.

\section{ACKNOWLEDGMENTS}

We would like to thank Dr. Dorath Pinto Uchôa for giving us the opportunity to examine such precious material. Also, we would like to thank Dr. Silvia Maranca and Dr. Veronica Wesolowski for helping us identify the origin of the archaeological material.

PML, AA, WS are research fellows of Conselho Nacional de Desenvolvimento Científico e Tecnológico (CNPq/Brazil). Fundings by CNPq, FAPERJ (Fundação Carlos Chagas Filho de Amparo à Pesquisa do Estado do Rio de Janeiro) and CAPES (Coordenação de Aperfeiçoamento de Pessoal de Nível Superior).

\section{REFERENCES}

1. Araujo A, Ferreira LF, Guidon N, Maues da Serra-Freire N, Reinhard K, Dittmar K. Ten thousand years of head lice infestation. Parasitol Today. 2000;16:269.

2. Arriaza B, Allison M, Standen V, Focacci G, Chacama J. Peinados precolombinos en momias de Arica. Chungara Rev Antropol Chilena. 1986;(16-17):353-75.

3. Arriaza B, Orellana NC, Barbosa HS, Menna-Barreto RF, Araújo A, Standen V. Severe head lice infestation in an Andean mummy of Arica, Chile. J Parasitol. 2012;98:433-6.

4. Arriaza B, Standen V. Bioarqueología: historia biocultural de los antiguos pobladores del extremo norte de Chile. Santiago de Chile: Editorial Universitaria; 2008.

5. Busvine JR. Insects and hygiene. London: Methuen; 1966

6. Callen E, Cameron TWM. A prehistoric diet revealed in coprolites. New Scientist. 1960;8:35-40 
DUTRA, J.M.F.; ALVES, A.D.; PESSANHA, T.; RACHID, R.; SOUZA, W.; LINARDI, P.M.; FERREIRA, L.F.; SOUZA, S.M. \& ARAÚJO, A. - Prehistorical Pediculus humanus capitis infestation: quantitative data and low vacuum scanning microscopy. Rev. Inst.Med. Trop. Sao Paulo, 56(2): 115-9, 2014.

7. Chamberlain AJ, Dawber RP. Methods of evaluating hair growth. Australas J Dermatol. 2003;44:10-8

8. Ewing HE. Lice from human mummies. Science. 1924;60(1556):389-90.

9. Ferris GF. The sucking lice. Mem Pacific Coast Entomol Soc. 1951;1:1-320.

10. Fonseca Filho O. Parasitismo e migrações humanas pré-históricas. Rio de Janeiro: Mauro Familiar; 1972.

11. Fornaciari G, Giuffra V, Marinozzi S, Picchi MS, Masetti M. "Royal" pediculosis in Renaissance Italy: lice in the mummy of the king of Naples Ferdinand II of Aragon (1467-1496). Mem Inst Oswaldo Cruz. 2009;104:671-2.

12. Harkey R. Anatomy and physiology of hair. Forensic Sci Int. 1993;63:9-18.

13. Hopkins GHE. The host-association of lice of mammals. Proc Zool Soc London. 1949;119:387-604

14. Horne P. Head lice from an Aleutian mummy. Paleopathol Newsl. 1979;25:7-8.

15. Leo NP, Campbell NJM, Yang X, Muncuoglu K, Barker SC. Evidence from mitochondrial DNA that head and body lice of humans (Phthiraptera: Pediculidae) are conspecific. J Med Entomol. 2002;39:662-6.

16. Light JE, Toups MA, Reed DL. What's in a name: the taxonomic status of human head and body lice. Mol Phylogenet Evol. 2008;47:1203-16.

17. Linardi PM, Botelho JR, de Maria M, Cunha HC. O significado do sítio de aderência das lêndeas de Pediculus capitis em amostras de cabelos recolhidos do chão de barbearias. Rev Soc Bras Med Trop. 1987;20:209-12.

18. Linardi PM, De Maria M, Botelho JR, Cunha HC, Ferreira JB. Prevalence of nits and lice in samples of cut hair from floors of barbershops and beauty parlors in Belo Horizonte, Minas Gerais State, Brazil. Mem Inst Oswaldo Cruz. 1988;83:471-4.
19. Owen BD. A model of multiethnicity: state collapse, competition, and social complexity from Tiwanaku to Chiribaya in the Osmore Valley, Peru. [PhD thesis]. Los Angeles: University of California; 1993

20. Raoult D, Dutour O, Houhamdi L, Jankauskas R, Fournier PE, Ardagna Y, et al. Evidence for louse-transmitted diseases in soldiers of Napoleon's Grand Army in Vilnius. J Infect Dis. 2006;193:112-20.

21. Raoult D, Reed DL, Dittmar K, Kirchman JJ, Rolain JM, Guillen S, et al. Molecular identification of lice from pre-Columbian mummies. J Infect Dis. 2008;197:535-43.

22. Reed DL, Light JE, Allen JM, Kirchman JJ. Pair of lice lost or parasites regained: the evolutionary history of anthropoid primate lice. BMC Biol. 2007;7:5-7.

23. Reinhard KJ, Buikstra J. Louse infestation of the Chiribaya culture, southern Peru: variation in prevalence by age and sex. Mem Inst Oswaldo Cruz. 2003;98(Supp 1):173-9.

24. Rick FM, Rocha GC, Dittmar K, Coimbra CEA Jr, Reinhard K, Bouchet F, et al. Crab louse infestation in pre-Columbian America. J Parasitol. 2002;88:1266-7.

25. Rivera MA, Mumcuoglu KY, Matheny RT, Matheny DG. Huevecillos de Anthropophthirus capitis, en momias de la tradición Chinchorro Camarones 15-d, norte de Chile. Chungara Rev Antropol Chilena. 2008;40:31-9.

26. Ruffer MA. Studies in the paleopathology of Egypt. Chicago: The University of Chicago Press; 1921

Received: 18 February 2013

Accepted: 26 June 2013 